\title{
Assessment genetic diversity of einkorn genotypes (Triticum monococ- cum L.) by gliadin electrophoresis
}

\author{
Gergana DESHEVA $^{1,2}$, Bozhidar KYOSEV ${ }^{1}$, Manol DESHEV ${ }^{1}$
}

Received January 09, 2020; accepted November 19, 2020. Delo je prispelo 09. januarja 2020, sprejeto 19. novembra 2020.

\begin{abstract}
Assessment genetic diversity of einkorn genotypes (Triticum monococcum L.) by gliadin electrophoresis

Abstract: The genetic diversity of gliadins in twenty two einkorn accessions preserved under long-term seed storage condition in the National gene bank of Bulgaria were evaluated, using acid polyacrylamide-gel electrophoresis (Acid-PAGE). In total, 64 polymorphic bands and 22 gliadin patterns were identified. Thirty four different mobility bands and 21 gliadin patterns were identified in the $\omega$-gliadin zone, 12 bands and 16 patterns were noted in the $\gamma$-gliadins, 17 patterns and 12 mobility bands were found for $\beta$-gliadins and six bands with five different $\alpha$-gliadin patterns were determined. The genetic diversity index $(\mathrm{H})$ was the highest for $\omega$-gliadins $(0.950)$, followed by $\beta$-gliadins (0.924) and $\gamma$ - $(0.914)$, respectively and the lowest value was detected in $\alpha$-gliadin patterns $(0.120)$. Cluster analysis based on the UPGMA method and Nei and Li similarity coefficients classified all the genotypes into 3 main groups. No relationships between genetic diversity, geographic origin and the genotypes were observed. The results of cluster analysis justify the high level of genetic variation among investigated einkorn accessions.
\end{abstract}

Key words: A-PAGE electrophoresis; einkorn; genetic diversity; gliadins
Ocenjevanje genetske raznolikosti genotipov enozrne pšenice (Triticum monococcum L.) z elektroforezo gliadinov

Izvleček: Genetska raznolikost gliadinov 22 akcesij enozrne pšenice, ki je bila shranjena $\mathrm{v}$ razmerah dolgotrajnega shranjevanja v nacionalni genski banki Bolgarije je bila ovrednotena s poliakrilamidno elektroforezo v kislem $\mathrm{pH}$ območju (Acid-PAGE). Celokupno je bilo ugotovljenih 64 polimorfnih prog in 22 vzorcev gliadinov. Določeno je bilo 32 različnih spremenljivih prog in 21 vzorcev gliadinov je bilo določenih znotraj $\omega$-gliadinov, 12 prog in 16 vzorcev je bilo znotraj $\gamma$-gliadinov, 17 vzorcev in 12 spremenljivih prog je bilo v območju $\beta$-gliadinov in 6 prog s petimi različnimi vzorci v območju $\alpha$-gliadinov. Indeks genetske raznolikosti $(\mathrm{H})$ je bil največji za $\omega$-gliadine $(0,950)$, ki su mu sledile vrednosti za $\beta$ - $(0,924)$ in $\gamma$-gliadine $(0,914)$. Najmanjše vrednosti indeksa so bile ugotovljene za a-gliadine $(0,120)$. Klasterska analiza, ki je temeljila na UPGMA metodi in koeficientu podobnosti po Nei in Li je razvrstila vse genotipe v tri glavne skupine. Ugotovljeno ni bilo nobene povezave med genetsko raznolikostjo, geografskim poreklom in genotipi. Rezultati klasterske analize so potrdili veliko genetsko variabilnost med analiziranimi akcesijami enozrne pšenice.

Ključne besede: elektroforeza A-PAGE; enozrna pšenica; genetska raznolikost; gliadini 


\section{INTRODUCTION}

Genetic diversity has played a vital role in the success of crop improvement. Knowledge of genetic diversity has been successfully used for efficient germplasm management and utilization, genetic fingerprinting and genotype selection (Engles et al., 2002; Aliyeva et al., 2012).

The electrophoresis of seed storage proteins used for variety fingerprinting is reliable, simple, repeatable and economic procedure. It can be utilized by wheat breeders to detect variability among wheat genotypes to identify new sources of variation that could be used in crop improvement programs (Aliyeva et al., 2012).

Gliadins are alcohol-soluble storage proteins that accounts for about $40 \%$, by mass, of all proteins of wheat flour. They are one of the most polymorphic proteins in nature and one of the major protein components of the human diet (Dziuba et al., 2014; Metakovsky et al., 2018). They are monomeric proteins with a molecular mass in the range of 35,000 to 70,000 daltons. (Shewry et al., 2002; Kuktaite, 2004; Meintjes, 2004; D’Ovidio \& Masci, 2004; Shuaib et al., 2007). When fractionated in acidic medium, they are divided into 4 major groups- $\alpha, \beta, \gamma$ and $\omega$ (Konarev, 1983; Bushuk, 1991). The genes controlling $\alpha$ - and $\beta$-gliadins were found to be located in the short arms of the chromosomes of the sixth (Gli-2) homologous group $-6 \mathrm{~A}, 6 \mathrm{~B}$ and $6 \mathrm{D}$, and of the $\gamma$ - and $\omega$-gliadins of the first (Gli-1) homeology group - 1A, 1B and 1D (Payne et al., 1987; Dachkevitch et al., 1993; Nieto-Taladriz et al., 1996; Branlard, 2004). A small group of gliadin fractions are encoded by genes located at Gli-3, Gli-4, Gli-5 and Gli-6 loci (Pogna et al., 1993; Rodriguez \& Carrillo, 1996; Metakovsky et al., 1997 a, 1997 b). An original methodology for their electrophoretic separation (A-PAGE) and a nomenclature for their designation (Bushuk \& Zilman, 1978; Bushuk \& Sapirstein, 1991) have been developed to detect the complex polymorphism of gliadins and to identify them. Intensive work with gliadins has been carried out in Ukraine and Russia (Metakovsky et al., 1984, 1986; Metakovsky \& Sozinov, 1987; Metakovsky \& Novoselskaya, 1991; Novoselskaya-Dragovich et al., 2003). Genetic polymorphism has been used to evaluate genetic diversity in wheat samples in Austria, Yugoslavia, Canada, Italy, France, Spain (Metakovsky et al., 1991, 1993, 1994, 1997 a, 1997 b, 2000; Metakovsky \& Branlard, 1998; Ruiz et al. , 2002 a, 2002 b; Branlard et al., 2001), Japan (Tanaka et al., 2003), China (Wu et al., 2007), India (Sewa et al., 2005), Pakistan (Anjum et al., 2000), Bulgaria (Stoyanova, 2002), Africa (Mohd et al., 2007). Based on the gliadin spectra, catalogs have been drawn up in some countries to identify varieties (Sapirstein \& Bushuk, 1986; Lookhart et al., 1983; Metakovsky et al.,
1991, 1994, 2018; Velkov, 1991; Stoyanova \& Kolev, 1996; Ruiz et al., 2002 a, 2002 b).

The allelic compositions at Gli-A1 and Gli-A2 loci in Triticum monococcum L. ssp. monococcum, Triticum monococcum ssp. boeoticum (Boiss.) C. Yen and Triticum urartu Thumanjan ex Gandilyan had investigated (Metakovsky \& Baboev, 1992, Saponaro et al., 1995; Zhao-cai et al., 2006). The high-quality gliadin alleles as Gli-A2b were found in einkorn wheat (Zhao-cai et al., 2006). In 40 accessions of Triticum boeoticum Boiss. and Triticum urartu Thumanjan ex Gandilyan collected from different regions of Iran, Ahmadi and Pour-Aboughadareh (2015) found that $92 \%$ of the accessions carried Gli-A2 allele detected by Long et al. (2005) and Kawaura et al. (2005). The variation in gliadin seed storage proteins in Spanish einkorn was high, with seven allelic variants for the Gli-Am1 locus and fourteen for the Gli-Am2 locus found among the evaluated accessions (Alvarez et al., 2006; Alvarez \& Guzmán, 2013).

The aim of this study was to compare the genetic diversity between einkorn genotypes with different geographic origin by electrophoretic patterns of seeds proteins.

\section{MATERIAL AND METHODS}

Twenty two einkorn accessions with different geographic origin preserved under long-term seed storage condition in the National gene bank of Bulgaria more than 20 years were evaluated by gliadin electrophoresis (Table 1).

Acid-PAGE (acid polyacrilamyde gel electrophoresis) was carried out according to the standard reference method of ISTA (Draper 1987; Anonymous 2003). Proteins were extracted from a bulk sample of $50 \mathrm{mg}$ finely ground powdered seeds with $300 \mu \mathrm{l}$ extracting solution ( $0.05 \mathrm{~g}$ Pyronin G; $25 \mathrm{ml}$ 2-chloroethanol), stained overnight at room temperature, and centrifuged for $30 \mathrm{~min}$ at $17000 \mathrm{~g}$ and $14^{\circ} \mathrm{C}$. Then, $10 \mu \mathrm{l}$ of the extracts were loaded into wells. Gliadin electrophoresis was performed on a vertical polyacrylamide gel with a thickness of $1.5 \mathrm{~mm}$ and an electrode buffer with a $\mathrm{pH}$ of 3.2 using a Consort E835 vertical unit (with gel cassette $200 \times 200 \mathrm{~mm}$ ). Electrophoresis was carried out at $20 \mathrm{~mA}$ for 5 hours and 15 minutes. Staining of gels was performed in a solution of Coomasie Brilliant Blue G-250: Coomasie Brilliant Blue R-250 (1:3), dissolved in trichloroacetic acid/methanol for 48 hours.

Specialized software BIO-1D++, version 11.07 was used to create databases for the gliadin spectra of the studied genotypes. Based on the results of electrophoretic band spectra, genetic similarity coefficient of Nei \& 
Table 1: List of accessions included in the study

\begin{tabular}{|c|c|c|c|c|c|}
\hline Number of the accessions & Genus & Species & Spaut. & Subtaxa & Origin \\
\hline BGR 19069 & Triticum & monococcum & $\mathrm{L}$. & var. hornemannii & Germany \\
\hline BGR 19065 & Triticum & monococcum & $\mathrm{L}$. & var. hornemannii & Georgia \\
\hline BGR 30035 & Triticum & monococcum & $\mathrm{L}$. & var. hornemannii & Russia \\
\hline BGR 19078 & Triticum & monococcum & $\mathrm{L}$. & var. laetissimum & Germany \\
\hline BGR 30022 & Triticum & monococcum & L. & var. laetissimum & Germany \\
\hline BGR 19061 & Triticum & monococcum & $\mathrm{L}$. & var. laetissimum & Spain \\
\hline BGR 19079 & Triticum & monococcum & $\mathrm{L}$. & var. nigricultum & Germany \\
\hline BGR 11001 & Triticum & monococcum & $\mathrm{L}$. & var. atriaristatum & Switzerland \\
\hline BGR 12386 & Triticum & monococcum & $\mathrm{L}$. & var. laetissimum & Germany \\
\hline BGR 19063 & Triticum & monococcum & $\mathrm{L}$. & var. flavescens & Spain \\
\hline BGR 30030 & Triticum & monococcum & $\mathrm{L}$. & var. eincorn & Russia \\
\hline BGR 30031 & Triticum & monococcum & $\mathrm{L}$. & var. vulgare & Russia \\
\hline BGR 30028 & Triticum & monococcum & $\mathrm{L}$. & var. hornemannii & Switzerland \\
\hline BGR 30026 & Triticum & monococcum & $\mathrm{L}$. & var. hornemannii & Switzerland \\
\hline BGR 28720 & Triticum & monococcum & $\mathrm{L}$. & var. macedonicum & Germany \\
\hline BGR 30036 & Triticum & monococcum & $\mathrm{L}$. & var. macedonicum & Russia \\
\hline BGR 19055 & Triticum & monococcum & $\mathrm{L}$. & var. flavescens & Germany \\
\hline B2E0417 & Triticum & monococcum & $\mathrm{L}$. & var. vulgare & Bulgaria \\
\hline B3E0025 & Triticum & monococcum & $\mathrm{L}$. & var. vulgare & Bulgaria \\
\hline BGR 28717 & Triticum & monococcum & $\mathrm{L}$. & var.eincorn & Russia \\
\hline BGR 30027 & Triticum & monococcum & $\mathrm{L}$. & var.albohornemannii & Germany \\
\hline BGR 26774 & Triticum & monococcum & L. & var.eredvianum & Germany \\
\hline
\end{tabular}

Li (1979) was calculated for all possible pair of electrophoregrams. The similarity matrix was used to construct the dendrogram by the unweighted pair group average method (UPGMA).

The genetic diversity for each gliadin pattern was calculated as per Nei (1973), as $H=1-\Sigma \mathrm{pi}^{2}$, where $\mathrm{H}$ is the genetic variation index and $\mathrm{Pi}$ is the proportion of a particular pattern in each group of $\alpha, \beta, \gamma$ and $\omega$ gliadins separately. The mean value of $\mathrm{H}$ was calculated for all the four groups of gliadins.

\section{RESULTS AND DISCUSSION}

In the Table 2 were presented number of gliadin bands, patterns, and the genetic variation index in gliadins for 22 investigated accessions of Triticum monococcum L. Among the 22 einkorn accessions analysed, 64 different bands were detected assuming that the bands with the same relative mobility represent the same protein. Each zone ( $\alpha, \beta, \gamma$ and $\omega$ ) was considered as a single locus and the different patterns as allelic variants.
The patterns within each gliadin group of $\alpha, \beta, \gamma$ and $\omega$ were identified by comparing banding patterns of each einkorn accession with all the other einkorn accessions (Ojaghi \& Akhundova, 2010; Aliyeva et al., 2012).

A total of 34 different mobility bands and 21 gliadin patterns were identified in the $\omega$-gliadin zone. Bands varied between two and seven in each $\omega$-gliadin pattern, as patterns with five bands being the most frequent $(40.9 \%)$. Twenty one accessions presented its unique $\omega$-gliadin pattern, while two genotypes had the same patterns, respectively 14-BGR 19055 and 15-B2E0417 with pattern 14 (Figure 1).

In the $\gamma$-gliadin zone, 12 bands and 16 different patterns were noted. The $\gamma$-gliadin pattern 5 , were observed in accessions 5-BGR 30022 and 19-BGR 30027. The pattern 6 was detected in 6-BGR 19061 and 7-BGR 19079. The $\gamma$-gliadin patterns 10 and 12 were marked respectively in two groups of accessions - 11-BGR 19063, 14-BGR 19055 and 15-B2E0417; 13-BGR 30026, 18-BGR 26774 and 20-BGR 28717 (Figure 1).

Seventeen $\beta$ - gliadin patterns and totally 12 different mobility bands were found. The bands in the gliadin 
Table 2: Number of gliadin bands, patterns, and the genetic diversity in gliadins for 22 accessions of Triticum monococcum L.

\begin{tabular}{|c|c|c|c|c|c|c|}
\hline \multirow[b]{2}{*}{ № } & \multirow[b]{2}{*}{ Accession number } & \multicolumn{4}{|c|}{ Number of gliadin bands } & \multirow[b]{2}{*}{ Total bands } \\
\hline & & $a$ & $\beta$ & $\gamma$ & $\omega$ & \\
\hline 1 & BGR 19069 & 3 & 4 & 2 & 5 & 14 \\
\hline 2 & BGR 19065 & 3 & 6 & 1 & 5 & 15 \\
\hline 3 & BGR 30035 & 4 & 4 & 4 & 4 & 16 \\
\hline 4 & BGR 19078 & 3 & 4 & 3 & 2 & 12 \\
\hline 5 & BGR 30022 & 4 & 3 & 4 & 5 & 16 \\
\hline 6 & BGR 19061 & 3 & 7 & 4 & 2 & 16 \\
\hline 7 & BGR 19079 & 3 & 4 & 4 & 3 & 14 \\
\hline 8 & BGR 11001 & 3 & 4 & 5 & 4 & 16 \\
\hline 9 & BGR 12386 & 4 & 3 & 4 & 6 & 17 \\
\hline 10 & BGR 19063 & 3 & 4 & 4 & 4 & 15 \\
\hline 11 & BGR 30031 & 3 & 5 & 3 & 3 & 14 \\
\hline 12 & BGR 30028 & 3 & 6 & 4 & 5 & 18 \\
\hline 13 & BGR 30026 & 4 & 5 & 4 & 4 & 17 \\
\hline 14 & BGR 19055 & 3 & 5 & 3 & 6 & 17 \\
\hline 15 & B2E0417 & 3 & 4 & 3 & 6 & 16 \\
\hline 16 & B3E0025 & 3 & 5 & 2 & 5 & 15 \\
\hline 17 & BGR 28720 & 3 & 5 & 4 & 3 & 15 \\
\hline 18 & BGR 26774 & 3 & 5 & 4 & 7 & 19 \\
\hline 19 & BGR 30027 & 3 & 5 & 4 & 5 & 17 \\
\hline 20 & BGR 28717 & 3 & 5 & 4 & 5 & 17 \\
\hline 21 & BGR 30036 & 3 & 5 & 4 & 5 & 17 \\
\hline 22 & BGR 30030 & 3 & 6 & 1 & 5 & 15 \\
\hline \multicolumn{2}{|c|}{ Range of gliadin bands } & $3-4$ & $3-7$ & $1-5$ & $2-7$ & $12-19$ \\
\hline \multicolumn{2}{|c|}{ Number of gliadin patterns } & 5 & 17 & 16 & 21 & 22 \\
\hline \multicolumn{2}{|c|}{ Genetic variation index $(\mathrm{H}, \%)$} & 0.120 & 0.924 & 0.914 & 0.950 & 0.727 \\
\hline
\end{tabular}

patterns varied from 3 to 7 bands, as patterns with five bands being the most frequent (45\%). Thirteen accessions had specific patterns in the $\beta$ - gliadin zone, while 1-BGR 19069 and 4-BGR 19078 with pattern 1, 2-BGR 19065, 20-BGR 28717 and 22-BGR 30030 with pattern 2, 3-BGR 30035 and 10-BGR 19063 with pattern 3, 5-BGR 30022 and 9-BGR 12386 with pattern 4 had the similar patterns (Table 2, Fig. 1).

Six bands were recorded in a-gliadin region and only five different $\alpha$-gliadin patterns were determined. Two numbers of accessions (3-BGR 30035 and 13-BGR 30026) had specific patterns, respectively patterns with numbers 2 and 5. $\alpha$-gliadin pattern with number 1 included ten accessions, pattern number three -2 accessions (5-BGR 30022 and 9-BGR 12386) and pattern number four - 8 accessions (6-BGR 19061, 7-BGR 19079, 8-BGR 11001, 10-BGR 19063, 11-BGR 30031, 12-BGR 30028,
14-BGR 19055, 18-BGR 26774). The accessions with three bands in the $\alpha$-gliadin zone predominate $(81.82 \%)$.

Considering the four zones together, 22 gliadin patterns were identified, as in BGR 26774- 19 bands and in BGR 30028- 18 bands were detected. The lowest numbers of bands were found in BGR 19078 genotype (Table 2).

According to the work of Metakovsky and Baboev (1992), two independent gliadin blocks were determined for each einkorn accession. The upper block was composed by $\omega$ - and $\gamma$-gliadins, and in some cases also by one slow moving $\beta$-gliadin, whereas the lower block was formed by $\beta$ - and $\alpha$-gliadins. These two blocks were encoded by the Gli-Alm and the Gli-A2m loci on the short arm of chromosomes 1 and 6, respectively. Ciaffi et al. (1997), in study of 74 accessions of T. monococcum from Italy, Greece, Turkey and Russia found more allelic variation at Gli-A1m than at Gli-A2m. In contras Alvarez et 


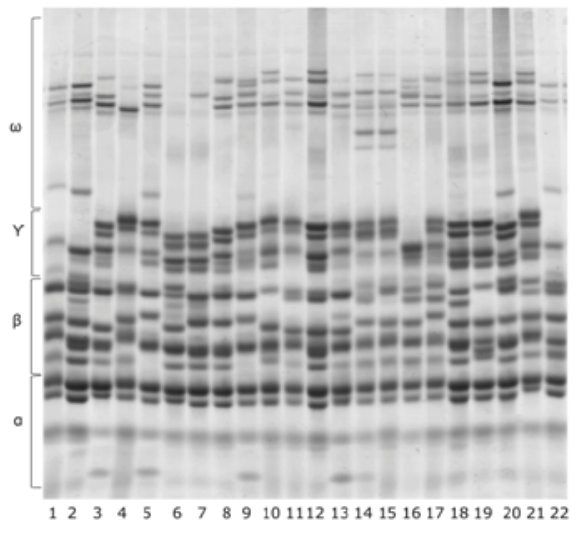

A)

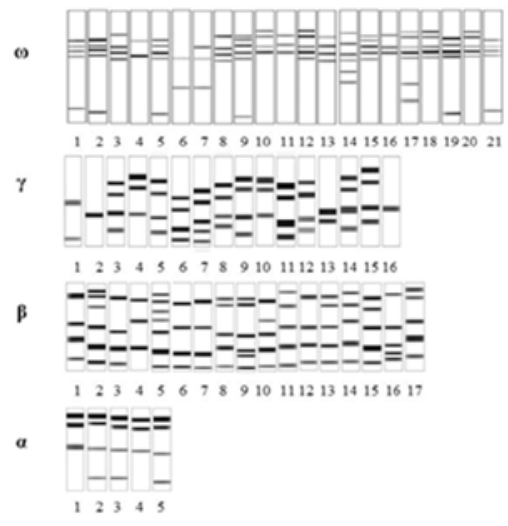

B)

Figure 1: A) Gliadin patterns of accessions of Triticum monococcum L. after acid polyacrylamide gel electrophoresis (A-PAGE) (1- BGR 19069, 2- BGR 19065, 3- BGR 30035, 4- BGR 19078, 5-BGR 30022, 6- BGR 19061, 7- BGR 19079, 8- BGR 11001, 9- BGR 12386, 10- BGR 19063, 11- BGR 30031, 12- BGR 30028, 13- BGR 30026, 14- BGR 19055, 15- B2E0417, 16- B3E0025, 17-BGR 28720, 18- BGR 26774, 19- BGR 30027, 20- BGR 28717, 21- BGR 30036, 22- BGR 30030); B). Ideograms of different gliadins patterns in the $\alpha, \beta, \gamma$ and $\omega$ regions

al. (2006) found 7 and 14 alleles for the Gli-A1m and Gli$A 2 m$ between the 48 evaluated einkorn accessions. Zhaocai et al. (2006) identified 14 and 19 allele variants, respectively at Gli-A1m and Gli-A2m of 41 T. monococcum accessions. Ruiz et al. (2007) noted that Gli-A2m was the most polymorphic and the most useful to distinguish between 17 einkorn varieties.

In this study, it was observed that $\omega, \gamma$, and $\beta$ areas had high allelic variants but the least allelic variants were established in area $\alpha$. The highest allelic variants had $\omega$ gliadins (Fig.1).

In investigated 22 einkorn genotypes, no identical gliadin patterns were found in the gliadin spectra. The genetic diversity based on the patterns was calculated for each of the four zones. The genetic variation indexes varied between 0.120 and 0.950 . Omega $(\omega)$ zone was found to have the biggest diversity $(\mathrm{H}=0.950)$, followed by $\beta(\mathrm{H}$ $=0.924)$ and $\gamma(\mathrm{H}=0.914)$ and the least diversity being that of $\alpha(\mathrm{H}=0.120)$. The mean value of $\mathrm{H}$ calculated for all the four groups of gliadins was also high $(\mathrm{H}=0.727)$ (Table 2). It indicated that high genetic variation existed in the einkorn wheat (Zhao-Cai et al., 2006).

The genetic similarities (GS) among 22 einkorn accessions estimated by Nei and Li coefficient (1979) are presented in Table 3. It ranged from 0.36 to 0.97 . The highest GS (0.97) was found between accessions: BGR 30022 (from Germany) and BGR 12386 (from Germany), BGR 19055 (from Germany) and B2E0417 (from Bulgaria), respectively, which indicates that the genetic diversity within these pairs of accessions was very low. The lowest value of GS was 0.36 , which was observed between accession BGR 30028 (from Switzerland) and BGR 30030 (from Russia).

Cluster analysis of gliadin bands using the UPGMA method, as well as Nei and Li (also called Dice) similarity coefficients is presented in Fig. 2. The correlation between the cophenetic value matrix and the original similarity coefficient matrix was high $(r=0.739)$ indicating a good fit of the cluster analysis performed (Ma et al., 2012). The dendrogram allowed distinguishing three main clusters. Cluster 1 included 6 genotypes. It was divided into three subgroups, The first subgroup included only genotype1-BGR 19069 (var. hornemannii from Germany). Subcluster 2 combined 3 genotypes: 2-BGR 19065 (var. hornemannii from Georgia), 22-BGR 28717 (var. eincorn from Russia) and 20-BGR 30030 (var. einkorn from Russia), which had pattern 2 in the $\beta$ zone and pattern 1 in a zone. Subgroup 3 included 4-BGR 19078 (var. laetissimum from Germany) and 21-BGR 30036 (var. macedonicum from Russia), which had pattern 1 in a zone. In cluster 2 were included 15 genotypes. The cluster was divided to two subgroups. The first subgroup grouped 3-BGR 30035 (var. hornemannii from Russia), 13-BGR 30026 (var. hornemannii from Switzerland), 5-BGR 30022 (var. laetissimum from Germany), 9-BGR 12386 (var. laetissimum, Germany), 10-BGR 19063 (var. flavescens from Spain), 12- BGR 30028 (var. hornemannii from Switzerland), 18-BGR 26774 (var. eredvianum from Germany), 19-BGR 30027 (var. albohornemannii from Germany), 6-BGR 19061 (var. laetissimum from Spain) and 7-BGR 19079 (var. nigricultum from Germany). The second subgroup included 5 genotypes, grouped also into three subgroups. In the first subgroup was separated 


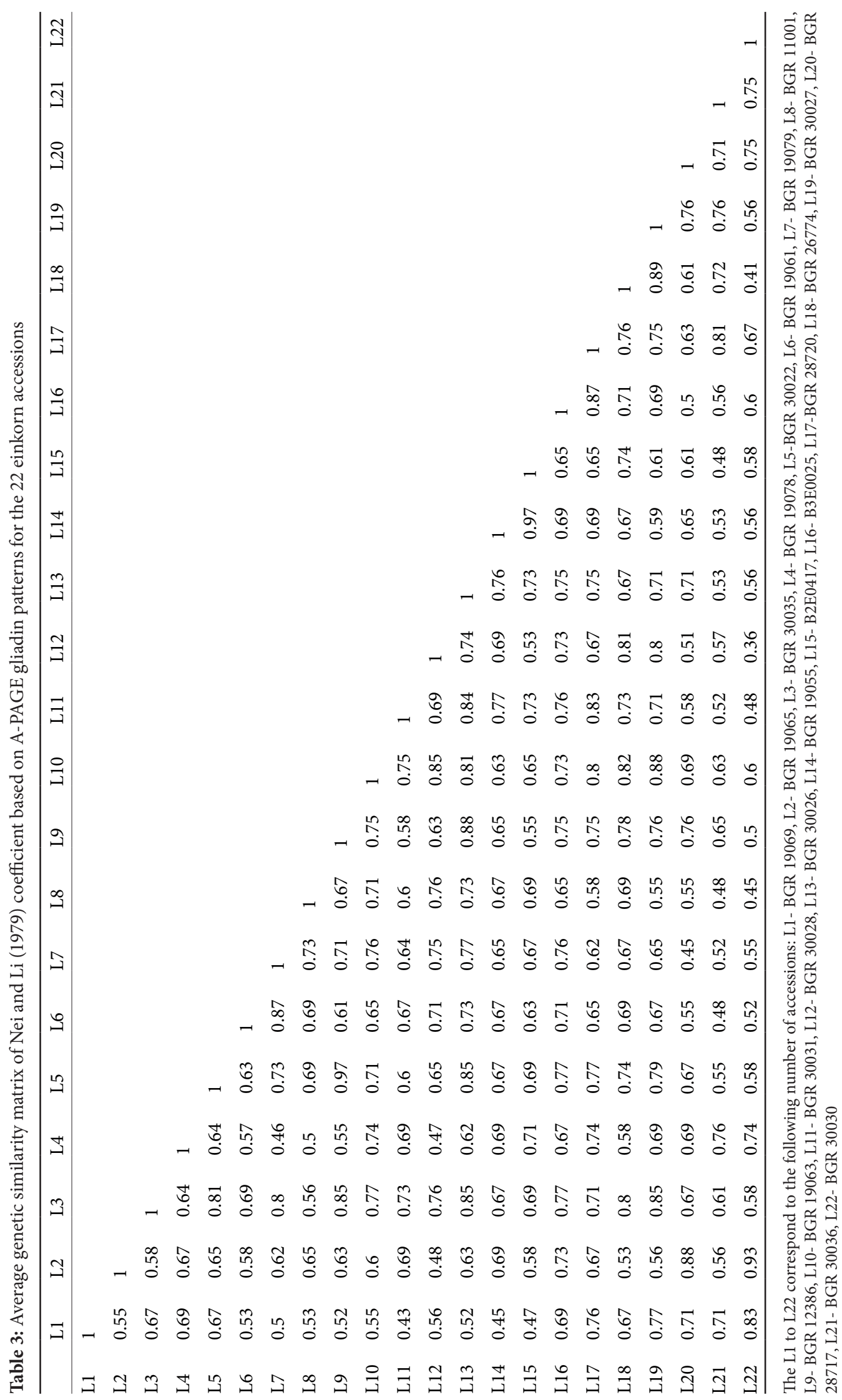




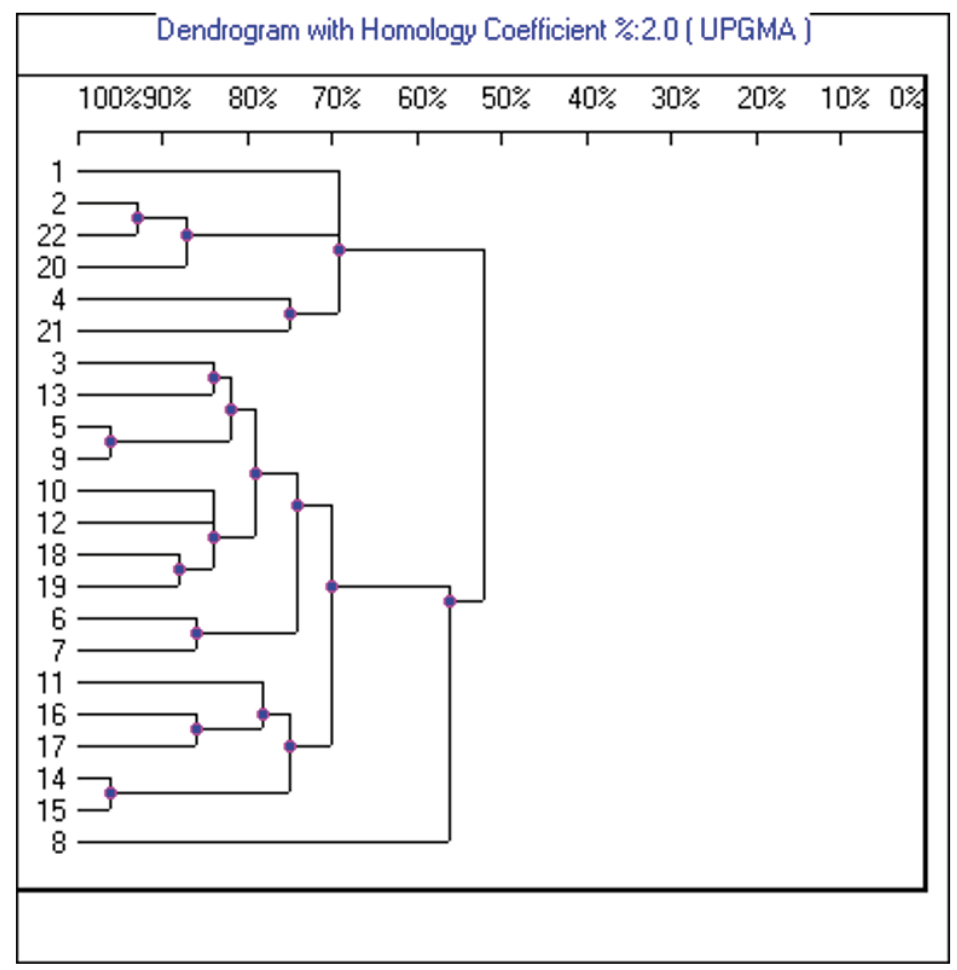

Figure 2: UPGMA dendrogram base on A-PAGE and Nei and Li similarity index (1- BGR 19069, 2- BGR 19065, 3- BGR 30035, 4- BGR 19078, 5-BGR 30022, 6- BGR 19061, 7- BGR 19079, 8- BGR 11001, 9- BGR 12386, 10- BGR 19063, 11- BGR 30031, 12BGR 30028, 13- BGR 30026, 14- BGR 19055, 15- B2E0417, 16- B3E0025, 17-BGR 28720, 18- BGR 26774, 19- BGR 30027, 20- BGR 28717, 21 - BGR 30036, 22- BGR 30030)

11-BGR 30031 (var. vulgare from Russia), into second respectively 16-B3E0025 (var. vulgare from Bulgaria) and 17-BGR 28720 (var. macedonicum from Germany), while in the third were 14-BGR 19055 (var. flavescens from Germany) and 15-B2E0417 (var. vulgare from Bulgaria), which had pattern 14 in the $\omega$-gliadin zone and pattern 10 in the $\gamma$-gliadin. In the last cluster 3 was separated genotype 8-BGR 11001 (var. atriaristatum from Switzerland). The results of cluster analysis justify the high level of genetic variation among einkorn genotypes. No relationships between genetic diversity, geographic origin and the genotypes were observed. Zhao-Cai et al. (2007) also confirmed that the genetic relationships in diploid wheats based on the gliadins were associated with the species or subspecies rather than the geographical origin. Khabiri et al. (2013) and Medouri et al. (2015) evaluated the relationships among 17 populations of Aegilops cylindrica Host and Aegilops geniculata Roth by gliadin polymorphism and found that genetic diversity did not follow the geographical distribution. Zaefizadeh et al. (2010) also found no correlation between genetic diversity and the geographical distribution of durum wheat landraces studied. A considerable differentiation of common wheat germplasms from different countries and breeding centres was discovered earlier using gliadin alleles as wheat genotype markers (Metakovsky et al., 1991, 1994; Chernakov and Metakovsky, 1994; Metakovsky and Branlard, 1998).

Additional investigation must to do to analyze population structure of einkorn wheat and relationships between agro-morphological data and gliadins.

\section{CONCLUSION}

The investigated 22 einkorn genotypes were characterized with high genetic diversity on the basis of their alcohol soluble proteins-gliadins by the acidPAGE method. The $\omega$-zone was the most polymorphic, followed by $\beta, \gamma$ and $\alpha$, respectively. The highest genetic similarities (GS) was found between accessions: BGR 30022 and BGR 12386, BGR 19055 and B2E0417, respectively. The lowest GS was observed between accession BGR 30028 and BGR 30030. The results of cluster analysis justify the high level of genetic variation among einkorn accessions. No relationship between genetic diversity, geographic origin and the genotypes was observed. 


\section{REFERENCES}

Ahmadi, J., \& Pour-Aboughadareh, A. (2015). Allelic variation of glutenin and gliadin genes in Iranian einkorn wheat. Journal of Biodiversity and Environmental Sciences, 7(5), 168-179.

Aliyeva, A., Ojaghi, J., Mehdiyeva, S. (2012). Electrophoretic profiles of gliadin subunits to evaluate genetic diversity of Azerbaijan synthetic branched spike wheat accessions. American-Eurasian Journal Agricultural and Environmental Science, 12(10), 1343-1349. https://www.idosi.org/aejaes/ jaes12(10)12/13.pdf

Alvarez, J. B., Moral, A., Martín, L. M. (2006). Polymorphism and genetic diversity for the seed storage proteins in spanish cultivated einkorn wheat (Triticum monococcum L. ssp. monococcum). Genetic Resources and Crop Evolution, 53(5), 1061-1067. https://link.springer.com/article/10.1007/ s10722-004-7940-9

Alvarez, J. B., \& Guzmán, C. (2013). Spanish ancient wheats: A genetic resource for wheat quality breeding. Advance in Crop Science and Technology, 1, 101. https://doi:10.4172/ acst.1000101

Anonymous. 2003. Protocol for distinctness, uniformity and stability tests. Barley. CPVO-TP 19/2; 06/11/2003, EU Community plant variety office, Angers.

Anjum, F. M., Lookhart, G., Walker, C. E. (2000). Electrophoretic identification of hard white spring wheats grown at different location in Pakistan in different years. Journal of the Science of Food and Agriculture, 80(8), 1155 - 1161. https://doi.org/10.1002/1097-0010(200006)80:8<1155::AIDJSFA587>3.0.CO;2-J

Branlard, G., Dardevet, M., Saccomano, R., Lagoutte, F., Gourdon, J. (2001). Genetic diversity of wheat storage proteins and bread wheat quality. Euphytica, 119(1-2), 59-67. https://doi: 10.1023/A:1017586220359

Branlard, G., (2004). Genetic determination of protein quality in wheat grain. International Workshop, Modelling quality traits and their genetic variability for Wheat, 18-21 July 2004, Clermont-Ferrand, France.

Bushuk, W., \& Zillman, R. R. (1978). Wheat cultivars identification by gliadin electrophoregrams. I.Apparatus, method and nomenclature. Canadian Journal of Plant Science, 58, 505-515. https://doi.org/10.4141/cjps78-076

Bushuk, W., \& Sapirstein, H. D. (1991). Modefied nomenclature for gliadins. In: W. Bushuk \& R. Tkachuk (Eds.), Gluten Proteins 1990, American Association of Cereal Chemists, (pages 454-458) Inc.,St. Paul, MN.

Chernakov, V.M., \& Metakovsky, E.V. (1994). Allelic variation at the gliadin-coding loci and evaluation of genetic similarity of common wheat cultivars bred in different breeding centers. Genetika, 30, 509-517.

Ciaffi, M., Dominici, L., Lafiandra, D. (1997). Gliadin polymorphism in wild and cultivated einkorn wheats. Theoretical Applied Genetics, 94, 68-74. https://doi: 10.1007/ s001220050383

D’Ovidio, R., \& Masci, S. (2004). The low-molecular-weight glutenin subunits of wheat gluten. Journal of Cereal Science, 39, 321-339. https://www.sciencedirect.com/science/article/pii/S0733521003001140
Dachkevitch, T., Redaelli, R., Biancardi, A. M., Metakovsky, E. V., Pogna, N. E. (1993). Genetics of gliadins coded by the group 1 chromosomes in the high-quality bread wheat cultivar Neepawa. Theoretical and Applied Genetics, 86(23), 389-399. https://link.springer.com/article/10.1007/ BF00222107

Draper, S. R. (1987). ISTA and 1987 Variety Committee. Report of the working group for biochemical tests for cultivar identification 1983-1986. Seed Science and Technology, 15, 431-437.

Dziuba, M., Nałęcz, D., Szerszunowicz, I., Waga, J. (2014). Proteomic analysis of wheat $\alpha / \mathrm{A}$ - and $\beta$-gliadins. Czech Journal of Food Science, 32, 437-442. https://www.agriculturejournals.cz/publicFiles/133171.pdf. https://doi. org/10.17221/600/2013-CJFS

Engles, J. M. M., Rao, V. R., Brown, A. H. D., Jackson, M. T. (2002). Managing plant genetic diversity, pp: 487. CABI Publishing, UK. ISSN 1818-6769, https://doi: 10.5829/idosi.aejaes.2012.12.10.6680

Kawaura, K., Mochida, K., Ogihara, Y. (2005). Expression profile of two storage-protein gene families in hexaploid wheat revealed by large-scale analysis of expressed sequence tags. Plant Physiology, 139, 1870-1880. http://www.plantphysiol.org/content/139/4/1870. https://doi.org/10.1104/ pp.105.070722

Khabiri, T., Zakaria A. R., Zare, N., Sofalian, O. (2013): Assessing genetic diversity based on gliadin proteins in Aegilops cylindrica populations from northwest of Iran. Notulae Scientia Biologicae, 5, 109-113. http://doi:10.15835/ nsb.5.1.8329

Konarev, V. G. (1983). Plant proteins cat genetic markers. Kolos, Moscow.

Kuktaite, R. (2004). Protein quality in wheat: changes in protein polymer composition during grain development and dough processing. Department of crop sciences Alnarp.

Long, H., Wei, Y., Yan, Z., H., Baum, B., Nevo, E., Zheng, Y. L. (2005). Classification of wheat low molecular-weight glutenin subunit genes and its chromosome assignment by developing LMW-GS group-specific primers. Theoretical and Applied Genetics, 111, 1251-1259. https://www.ncbi. nlm.nih.gov/pubmed/16187122. https://doi.org/10.1007/ s00122-005-0024-1

Lookhart, G., Jones, B., Walker, D., Hall, S., Cooper, D. (1983). Computer-assisted method for identifying wheat cultivars from their gliadin electrophoregrams. Cereal Chemistry, 60(2), 111-115.

Ma, X., Chen, Sh., Zhang, X., Bai, Sh., Zhang, C. (2012). Assessment of worldwide genetic diversity of Siberian wild rye (Elymus sibiricus L.) germplasm based on gliadin analysis. Molecules, 17, 4424-4434. http://doi:10.3390/molecules 17044424

Meintjes, G. D. (2004). The used HPLC for quality predriction of South African wheat cultivars. University of Free State Bloemfontein.

Metakovsky, E. V., \& Branlard, G. (1998). Genetic diversity of French common wheat germplasm based on gliadin alleles. Theoretical and Applied Genetics, 96, 209-218. https:// doi:10.1007/s001220050729

Metakovsky, E. V., Branlard, G., Chernakov, V. M., Upelniek, V. 
P., Redaelli, R. E. (1997b). Recombination mapping of some chromosome 1A-, 1B-, 1D- and 6B-controlled gliadins and low-molecular-weight glutenin subunits in common wheat. Theoretical and Applied Genetics, 94(6-7), 788-795. https:// doi.org/10.1007/s001220050479

Metakovsky, E. V., Gómez, M., Vázquez, J. F., Carrillo, J. M. (2000). High genetic diversity of Spanish common wheats as judged from gliadin alleles. Plant Breeding, 119, 37. https://doi.org/10.1046/j.1439-0523.2000.00450.x

Metakovsky, E. V., \& Novoselskaya, A. (1991). Gliadin allele identification in common wheat. Journal of Genetics \& Breeding, 45, 317-344.

Metakovsky, E. V., Aniechiarico, P., Boggini, G., Pogna, N. (1997a). Relationship between gliadin alleles and dough strength in Italian bread wheat cultivars. Journal of Cereal Science, 25, 226-229. https://doi.org/10.1006/jcrs.1996.0088

Metakovsky, E. V., Chernakov, V., Pogna, N., Bushuk, W. (1993). Gliadin alleles in Canadian western red spring wheat cultivars: use of two different procedures of acid polyacrylamide gel electrophoresis for gliadin seperation. Genome, 36, 743 749. https://doi:10.1139/g93-099

Metakovsky, E. V., Knežević, D., Javornik, B. (1991). Gliadin allele composition of Yugoslav winter wheat cultivars. Euphytica, 54, 285-295. https://doi.org/10.1007/BF00023005

Metakovsky, E. V., Pogna, N., Biancardi, A., Redaelli, R. (1994). Gliadin allele composition of common wheat cultivars grown in Italy. Journal of Genetics \& Breeding, 48, 55-66.

Metakovsky, E. V., \& Sozinov, A. A. (1987). Organization variability and stability of the family of the gliadin-coding genes in wheat: genetic data. Proceeding of the $3^{\text {rd }}$ Internat. Workshop on Gluten Proteins, Budapest Hungary, May 9-12, 30-45(ed. R. Lasztity, F. Bekes), World Scientific.

Metakovsky, E. V, Akhmedov, M. G., Sozinov, A. A. (1986). Genetic analysis of gliadin-encoding genes reveals gene clusters as well as single remote genes. TAG, 73, 278-285. https://doi.org/10.1007/BF00289286

Metakovsky, E. V, Novoselskaya, A., Yu, Sozinov, A. A. (1984). Genetic analysis of gliadin components in winter wheat using two-dimensional Polyaclylamide gel electrophoresis. Teoretical Applied Genetics, 69, 31-37. https://doi. org/10.1007/BF00262533

Metakovsky, E., Melnik, V., Rodriguez-Quijano, M., Upelniek, V., Carrillo, J. M. (2018). A catalog of gliadin alleles: Polymorphism of 20th-century common wheat germplasm. The Crop Journal, 6, 628-641. https://doi.org/10.1016/j. cj.2018.02.003

Metakovsky, E. V., \& Baboev, S. K. (1992). Polymorphism and inheritance of gliadin polypeptides in T. monococcum L. Theoretical and Applied Genetics, 84, 971-978. https://doi. org/10.1007/BF00227412

Mohd, S., Alam, Z., Zahir, A., Waqar, A., Taufiq, A., Khan, I. (2007). Characterization of wheat varieties by seed storage protein electrophoresis. African Journal of Biotechnology, 6 (5), 497-500. https://doi: 10.4314/ajb.v6i5.56863

Nei, M., \& Li, W. H. (1979). Mathematical model for studying genetic variation in terms of restriction endonucleases. Proceeding of the National Academy of Science of the United States of America, 76, 5269-5273.

Nei, M. (1973). Analysis of gene diversity in subdivided popu- lations. Proceedings of the National Academy of Sciences of the United States of America, 70, 3321-3323. https://doi. org/10.1073/pnas.70.12.3321

Nieto-Taladriz, M. T., \& Carrillo, J. M. (1996). Complexity of the Gli-A3 locus in bread wheat. Plant Breeding, 115, 192. https://doi.org/10.1111/j.1439-0523.1996.tb00900.x

Novoselskaya-Dragovich, A., Krupnov, V. A., Saifulin, R. A., Pukhalskiy, V. A. (2003). Dynamics of genetic variation at gliadin-coding loci in Saratov cultivars of common wheat Triticum aestivum L. over eight decades of scientific breeding. Russian Journal of Genetics, 39, 1130-1137. https://doi. org/10.1023/A:1026170709964

Ojaghi, J., \& Akhundova, E. (2010). Genetic diversity of gliadin pattern, morphological traits and baking quality in doubled haploid wheat. African Journal of Biotechnology, 9(7), 956-966. https://www.ajol.info/index.php/ajb/article/ view/78158. https://doi.org/10.5897/AJB09.728

Payne, P., Seekings, J., Worland, A., Jarvis, M., Holt, G. (1987). Allelic variation of glutenin sub-units and gliadins and its effect on bread-making quality in wheat. Journal of cereal science, 6, 103-118. https://doi.org/10.1016/S07335210(87)80047-4

Pogna, N., Metakovsky, R., Radaelli, R., Raeneri, F., Dachkevich. (1993). Recombination mapping of Gli-5 a new gliadin-coding locus on hromosome 1-A and 1-B in common wheat. Teoretical and Applied Genetics, 87, 113-121. https:// doi: 10.1007/BF00223754

Rodriguez, M., \& Carrillo, J. (1996). Linkage map of prolamin loci Gli-D4 and Gli-D5 in hexaploid wheat. Plant Breeding, 115, 189-191. https://doi:10.1111/j.1439-0523.1996. tb00899.x

Ruiz, M., Metakovsky, E. V., Rodriguez-Quijano, M., Vazquez, J. F., Carrillo, J. M. (2002b). Assessment of storage protein variation in relation to some morphological characters in a sample of Spanish landraces of common wheat (Triticum aestivum L. ssp. aestivum). Genetic Resources and Crop Evolution, 49(4), 373-384. https://doi:10.1023/A:1020626430815

Ruiz, M., Rodriguez-Quijano, M., Metakovsky, E. V., Vazquez, J. F., Carrillo, J. M. (2002a). Polimorphism, variation and genetic identity of Spanish common wheat germplasm based on gliadin alleles. Field Crops Research, 79(2), 185196. https://doi:10.1016/S0378-4290(02)00139-9

Ruiz, M., Aguiriano, E., Fité, R., Carrillo, J. M. (2007). Combined use of gliadins and SSRs to analyse the genetic variability of the Spanish collection of cultivated diploid wheat (Triticum monococcum L. ssp. monococcum). Genetic Resources and Crop Evolution, 54(8), 1849-1860. https://doi. org/10.1007/s10722-007-9208-7

Sapirstein, H., \& Bushuk, W. (1986). Computer-aided wheat cultivar identification and analysis of densitometric scanning profiles of gliadin electrophoregrams. Seed Scienced Technology, 14, 489-517.

Saponaro, C, Pogna, N., Castagna, R., Pasquini, M., Cacciatori, P., Redaelli, R. (1995). Allelic variation at the GliA1, GliA2 and GluA1 loci and quality in diploid wheat Triticum monococcum evaluated with SDS sedimentation test. Genetic Resources, 66, 127-137. https://doi.org/10.1017/ S0016672300034479

Sewa, R., Nisha, J., Vinamrata, D., Singh, R., Shoran, J. (2005). 
Analyses of acid-PAGE gliadin pattern of Indian wheat representing different environments and periods. Crop Science, 45, 1256-1263. https://doi:10.2135/cropsci2004.0334

Shewry, P., \& Halford, N. G. (2002). Cereal seed storage proteins: structures, properties and role in grain utilization. Journal of Experimental Botany, 53(370), 947-958. https:// doi:10.1093/jexbot/53.370.947

Shuaib, M., Zeb, A., Ali, Z., Ali, W., Ahmad, T., Khan, I. (2007). Characterization of wheat varieties by seed storageprotein electrophoresis. African Journal of Biotechnology, 6(5), 497500. https://doi:10.4314/ajb.v6i5.56863

Stoyanova, S., \& Kolev K. (1996). Identification of varieties of soft wheat by electrophoresis of the gliadin fraction. Plant Science, 35, 5-9.

Stoyanova, S. D. (2002). Weat genetic resources evalutation by electrophoretic separation of gliadins. Jurnal of Biotechnology and Biotechhnological Equipment, 16, 3-7. https://doi.or g/10.1080/13102818.2002.10819147

Tanaka, H., Tomita, M., Tsujimoto, H., Yasumuro, Y. (2003). Limited but specific variation of seed storage proteins in Japanese common wheat (Triticum aestivum L.). Euphytica, 132, 167-174. https://doi.org/10.1023/A:1024638616507
Velkov, B. (1991). Catalog of wheat electrophoregram varieties. Crop Science, 40, 17-23.

Wu, F., Han, Z. X., Liu, Y., Pan, Z. F., Deng, G. B., Yu, M. Q. (2007). Unique gliadin patterns in Chinese winter wheat cultivars. Plant Breeding, 126(5), 498-502. https:// doi:10.1111/j.1439-0523.2007.01358.x

Zaefizadeh, M., Somarin, S.J., Ojaghi, J., Seyedi, S.M., Mahmoodabad, R.Z., Ochi, M. (2010). Genetic diversity for gliadin patterns of durum wheat landraces in the Northwest of Iran and Azerbaijan. Pesquisa Agropecuária Brasileira, 45, 1425-1432. https://doi:10.1590/S0100204X2010001200013

Zhao-Cai, M., Chen, Q., Zheng, Y. (2006). Allelic identification and genetic diversity at Gli-Aland Gli-A2 loci in einkorn wheat. International Journal of Agricultural Research, 1, 100-107. https://doi:10.3923/ijar.2006.100.107

Zhao-Cai Ma, Yu-Ming Wei, Ze-Hong Yan, You-Liang Zheng. (2007). Genetic variations of gliadin and high-molecularweight glutenin subunits in diploid wheats. PGR Newsletter, $150,10-15$ 